Advanced Studies in Medical Sciences, Vol. 1, 2013, no. 3, 125 - 142

HIKARI Ltd, www.m-hikari.com

\title{
Fears, Phobias and Disgust Related to Bees
}

\section{and other Arthropods}

\author{
K. Münstedt and A. K. Mühlhans \\ University Hospital Giessen and Marburg, Klinikstrasse 33 \\ 35392 Giessen, Germany
}

Copyright (C) 2013 K. Münstedt and A. K. Mühlhans. This is an open access article distributed under the Creative Commons Attribution License, which permits unrestricted use, distribution, and reproduction in any medium, provided the original work is properly cited.

\begin{abstract}
Fears and phobias exist related to bees, spiders and other small arthropods; however, there are few studies to date which analyse differing views about various arthropods in relation to their potential dangers and ecological and economical benefits, especially the honey bee. Knowledge of these issues could help to improve potential conflicts between beekeepers and their anxious neighbours.

We assessed attitudes towards various arthropods-wasps, hornets, bees, woodlouse (slater, sowbug) and ladybirds-based on earlier questionnaires concerning spider phobia in 223 randomly selected participants, and related them to personality factors assessed by various standardized questionnaires. Furthermore, we determined the perceived mortality risk arising from the potential threat of various arthropods in relation to various other causes of death, and compared the data to the exact figures supplied by the German Federal Office for Statistics.
\end{abstract}


Factor analysis and varimax rotation identified three underlying dimensions: "knowledge of the arthropod", "dangers associated with arthropods" and "anxiety and disgust". We found that ratings of the participants regarding the various animals differed significantly and that personality factors greatly influenced these ratings. Our study showed that knowledge of an arthropod clearly reduces the perceived associated danger. Regarding the perceived rates of mortality from bees and wasps, the risk is clearly overestimated in contrast to risks which were assumed voluntarily by individuals.

This paper shows that people differ in their attitudes to various arthropods. Although bees are considered somewhat less dangerous and repellent compared to hornets, wasps and spiders, the actual risks remain overestimated. The data provide evidence that improving knowledge of arthropods can reduce fears, and thus also reduce potential conflicts between beekeepers and their neighbours.

Keywords: phobia, insects, fear

\section{Introduction}

Fear and anxiety are defined as distressing emotions aroused by impending danger, evil or pain, which may be real or imagined. They are together regarded as an important protective mechanism against various threats, increasing vigilance, learning and general performance. Both must be separated from phobias, which are persistent, irrational fears of specific objects, activities, or situations leading to a compelling desire to avoid them. Phobias represent a common problem. According to the National Comorbidity Survey of 1994, the lifetime prevalence of anxiety disorders is $31.2 \%$, and the prevalence of specific phobias is $\quad 12.5 \%$ (http://www.hcp.med.harvard.edu/ncs/ftpdir/NCSR_Lifetime_Prevalence_Estimates.pdf; Magee et al., 1996), which is similar to a later survey from Germany (Wittchen et al., 1999). Phobias are more frequently found in women (http://www.hcp.med.harvard.edu/ncs/ftpdir/NCSR_Lifetime_Prevalence_Estimates.pdf; Wittchen et al., 1999). Phobias concerning animals and birds are among the commonest of all. A recent study from the Netherlands found that fear of snakes (34.8\%), heights (30.8\%), physical injuries (27.2\%) and dental fear (24.3\%) were the most common. Among phobias, dental phobia was the most common (3.7\%), followed by height (3.1\%) and spider phobia (2.7\%) (Oosterink et al., 2009). Phobias related to bees and wasps 
have also been reported in addition to those related to spiders (Brough et al., 1965; Fahrig, 1972; Hartie, 1975; Brown et al., 2003). Animal phobias are believed either to develop during childhood in conjunction with an inappropriate assessment of the risk, or may be biologically preformed (Morschitzky, 2009). Dangers associated with snakes, pain and swelling associated with stings from venomous insects, the issue of mass envenomation, especially that associated with the Africanized honey bee, and the problems of sting-related allergies, are probably all reasons promoting a fear related to bees, hornets and wasps (Mathew et al., 2011; West et al., 2011). Although dangerous spiders are found in some regions of the world (Braitberg \& Segal, 2009), phobias related to insects (entomophobias) are generally believed to result from revulsion rather than actual threat (Morschitzky, 2009).

Since there is no significant differentiation between phobias related to spiders and small insects, we undertook this study to find out whether different views exist in relation to the potential dangers and ecological and economical benefits due to various arthropods, especially the honey bee. The results are likely to be important for beekeepers, who are sometimes confronted by anxious neighbours who insist that the bees are removed.

\section{Materials and methods}

In the study we used several methods to assess attitudes towards spiders, wasps, bees, woodlice (slater, sowbug) and ladybird beetles, using various questionnaires.

\section{Dependent measurements}

Based on earlier research into spider phobia (Szymanski \& O'Donohue, 1995) we supplemented the questionnaire by investigating aspects that could also be attributed to other arthropods, namely wasps, hornets, bees, woodlice (slater, sowbug) and ladybird beetles. The new questionnaire assessed both previously tested and additional aspects relating to spiders and the other above-mentioned arthropods. The ladybird beetle was selected as a control animal as it is not associated with any kind of danger and disgust.

We also assessed positive effects (honey production, environmental benefit, utility) of the named animals in order to identify a potential cognitive influence and used these effects as independent variables. Furthermore, we investigated both trait and state anxiety using the state-trait-anxiety inventory (STAI) (Laux et 
al., 1981). The different aspects of personality dimensions were investigated using the German versions of the positive and negative affect schedule (PANAS) (Krohne et al., 1996) and the NEO-Five-Factor Inventory (NEO-ffi) (Borkenau \& Ostendorf, 1993).

\section{Results}

Between January 2010 and October 2010 the questionnaire was distributed to 300 randomly selected probands who were willing to complete it. Two hundred and twenty three were returned (response rate $74.3 \%$ ). Characteristics of the probands are shown in Table 1.

\section{Identification of underlying dimensions}

Using factor analysis and varimax rotation, a three-factor solution was identified. For each dimension, items were selected using the highest loadings to construct the relevant scales. The description of the resulting scale items and Cronbach's alpha are depicted in Table 2. With reference to the predominant topics addressed in each scale, we characterized scale 1 as "knowledge of the arthropod" or "knowledge" in brief; scale 2 as "dangers associated with arthropods" or “danger”; and scale 3 as "anxiety and disgust” (Table 2). We found significant differences between the different arthropods in the three scales (Figure 1).

Simple correlation analysis between these scales and the various independent variables showed that all scales correlated with several aspects of personality. Higher coefficients of correlation were found between "knowledge" and "openness" and "knowledge" and "health and environment" (Table 3). Inverse correlations were found between "knowledge" and "danger" as well as "anxiety and disgust” (Table 3), which suggests an increasing knowledge leads to a lower perception of danger, and reduced anxiety and disgust towards the investigated arthropods. Correlations regarding "knowledge" showed that probands who were better informed about one arthropod were also likely to know more about another. They also had better knowledge of beehive products and the ecological role of honey bees. Regarding “danger”, we found significant correlations with "anxiety and disgust", state and trait anxiety, neuroticism, and positive affects. This scale is negatively associated with agreeableness and openness, which means that probands with a higher perception of the dangers associated with the arthropods being studied are less agreeable and less open to new experiences (Table 4). Our findings were basically similar for "anxiety and disgust” (Table 5). Interestingly, 
gender and age do not seem to influence greatly the three scales "knowledge", "danger" or "anxiety and disgust".

We also asked probands to estimate the number of deaths associated with various activities or problems. We divided the given answers by the actual numbers obtained from the Statistisches Bundesamt (Federal Office for Statistics, http://www.destatis.de). The quotients of the medians are depicted in Figure 2, which illustrates that: the risks of tobacco smoking, household and motorcycle accidents are clearly underestimated; the risk of death due to fire in apartments or dam collapse were estimated correctly; and the risk of death due to lightning strike or involvement in a plane crash, as well as dangers associated with arthropods, are overestimated. The quotients were also correlated to psychological factors: interestingly, we found no significant correlation, which means that personality factors do not influence underestimation or overestimation of the named risks.

Finally, using the same method, we investigated factors associated with what an individual might consider in thinking of becoming a beekeeper. Discriminant analysis excluded all psychological factors. Including the scales investigated here, we were able to identify the factors: a belief in the ecological role of bees and health issues related to bee products (exact $F=29.7$ ); dangers associated with bees (exact $F=19.9$ ); danger associated with ladybirds (exact $F=5.0$ ); and estimated risk of death due to bee attacks (exact $F=4.0$ ). Using these factors it was possible to identify $74.1 \%$ of people who might contemplate keeping bees (Wilk's lambda $=0.777 ;$ chi $^{2}=49.7 ; \mathrm{df}=4 ; \mathrm{p}<0.001$ ).

\section{Discussion}

To the best of our knowledge, this is one of the first analyses to investigate the views of people about various arthropods. It showed that stinging hymenoptera hornets, wasps and bees are considered to be the most dangerous arthropods and that hornets and spiders produce the highest levels of anxiety and revulsion. We determined that knowledge of various arthropods is inversely correlated with perceived danger, anxiety and disgust. The study supports the finding that spiders produce high levels of anxiety and disgust, with only hornets producing higher levels. Although anxiety and disgust may generally be separated from each other, we were unable to distinguish between them because our questionnaire did not allow such differentiation (Vernon \& Berenbaum, 2004; Vernon \& Berenbaum, 
2008). We omitted this aspect from our study because no earlier study reported associations between bees and disgust. In this respect, a recent study which assessed differences regarding the attitudes towards various arthropods found that disgust is mainly associated with spiders (Gerdes et al., 2009). This is in accordance with earlier publications (De Jong et al., 1997). Gerdes et al. (2009) investigated reactions of psychology students towards spiders, bees, wasps, beetles, butterflies and moths. Unfortunately, they combined the ratings for bees and wasps, which we found to differ significantly. Gerdes et al. (2009) also reported that spiders were rated as the most feared, disgusting and dangerous of animals. This contrasts with our findings on the perceived danger associated with spiders. The participants in our study clearly gave a more accurate estimation of the danger associated with spiders. Our questionnaire differentiated between the more reasonable and rational aspects of the dangers associated with arthropods and emotional fears. An aspect relating to disgust could be included in further studies as it was shown to be a motivator for avoiding arthropods (Woody et al., 2005). We also found that several personality factors are linked to the three scales "knowledge”, “danger”, and "anxiety and disgust”. Finally, we showed that the dangers associated with arthropods are clearly overestimated in contrast to the many dangers of daily life, which are underestimated. As shown by Fischhoff et al. (1978), the perception of a certain risk may be influenced by several factors, including whether it was taken voluntarily, immediacy of effect, knowledge about the risk (by the person exposed to the risk), knowledge about the risk (known to science), control over the risk, lack of familiarity, common-dread, and the severity of consequences. With this background in mind it is understandable that the risks of smoking, driving a motorcycle and household accidents are underestimated because they are voluntarily agreed upon, individuals believe themselves to be in control of the risk and there is no immediacy of effect. The risks of stinging and biting insects are overestimated because people do not usually expose themselves to them, they are a common dread, and there is an immediate and problematic result in cases of allergic reactions. The usefulness of the risk factor is also considered, which could explain why honeybees seem to have a better reputation than hornets and wasps.

It was shown that both virtual but especially in vivo exposure might be helpful for reducing the problems of phobias (Michaliszyn et al., 2010). However, with regard to our finding that knowledge is inversely correlated with disgust, we believe that improving knowledge about arthropods and their ecological importance could be another approach to reducing anxiety and disgust. This could also lead to a more rational perception of the risks associated with various 
arthropods. Future investigations into attitudes towards bees should include questions that could allow a better differentiation between anxiety and disgust.

\section{Acknowledgements}

The authors thank Mr. Richard von Georgi from the Institute of Medical Psychology for providing the questionnaires for this research.

\section{References}

P. Borkenau, F. Ostendorf, NEO-Fünf-Faktoren-Inventar nach Costa und McCrae,Manual. 2. Aufl. Hogrefe Verlag; Göttingen, 2008

M.M. Bradley, P.J. Lang, Measuring emotion: the self-assessment manikin and the semantic differential, Journal of Behavioral Therapy and Experimental Psychiatry, 25 (1994), 49-59.

G. Braitberg, L. Segal, Spider bites - assessment and management, Australian Family Physician, 38(11), (2009), 862-867.

D.I. Brough, N. Yorkston, D. Stafford-Clark, A case of wasp phobia treated by systematic desensitization under light hypnosis, Guy's Hospital Reports, 114(3), (1965), 319-324.

J.S. Brown, S. Abrahams, M. Helbert, An unusual case of a wasp phobic, Journal of Behavior Therapy and Experimental Psychiatry, 34(3-4), (2003), 219-224.

P.J. De Jong, H. Andrea, P. Muris, Spider phobia in children: disgust and fear before and after treatment, Behaviour Research and Therapy, 35(6), (1997), 559562.

H. Fahrig, Kurztherapie eines sechsjährigen Mädchens mit Bienenphobie [Short therapy of a 6-year-old girl with bee phobia], Praxis der Kinderpsychologie und Kinderpsychiatrie, 21(5), (1972), 161-166. 
B.P. Fischhoff, S. Slovic, S. Lichtenstein, S. Read, B. Combs, How safe is safe enough? A psychometric study of attitudes towards technological risks and benefits, Policy Sciences, 9, (1978), 127-152.

A.B.M. Gerdes, G. Uhl, G.W. Alpers, Spiders are special: fear and disgust evoked by pictures of arthropods, Evolution and Human Behavior, 30, (2009), 66-73.

A. Hartie, Phobia of bees and wasps. Nursing Times, 71(13), (1975), 488-491.

H.W. Krohne, B. Egloff, C.W. Kohlmann, A. Tausch, Untersuchungen mit einer deutschen Version der "Positive and Negative Affect Schedule" (PANAS), Diagnostica, 42(2), (1996), S139-156.

L. Laux, P. Glanzmann, P. Schaffner, C.D. Spielberger, Das State-TraitAngstinventar, Manual, 1. Aufl, Weinheim; Beltz, 1981.

W.J. Magee, W.W. Eaton, H.U. Wittchen, K.A. McGonagle, R.C. Kessler. Agoraphobia, simple phobia, and social phobia in the National Comorbidity Survey, Archives of General Psychiatry, 53(2), (1996), 159-168.

A. Mathew, A Christpal, T. David, Acute myocardial injury and rhabdomyolysis caused by multiple bee stings, Journal of the Association of Physicians of India, 59, (2011), 518-520.

D. Michaliszyn, A. Marchand, S. Bouchard, M.O. Martel, J. Poirier-Bisson, A randomized, controlled clinical trial of in virtuo and in vivo exposure for spider phobia, Cyberpsychology, Behavior and Social Networking, 13(6), (2010), 689695.

H. Morschitzky, Angststörungen - Diagnose, Konzepte, Therapie, Selbsthilfe, Springer; New York, 2009, 705 pp.

F.M. Oosterink, A. De Jong, J Hoogstraten, Prevalence of dental fear and phobia relative to other fear and phobia subtypes. European Journal of Oral Science, 117(2), (2009), 135-143. 
J. Szymanski, W. O’Donohue, Fear of Spiders Questionnaire. Journal of Behavioral Therapy and Experimental Psychiatry, 26(1), (1995) S31-34.

L.L. Vernon, H. Berenbaum, A naturalistic examination of positive expectations, time course, and disgust in the origins and reduction of spider and insect distress. Journal of Anxiety Disorders, 18(5), (2004), 707-718.

L.L. Vernon, H. Berenbaum, Fear and disgust propensity in spider phobic distress. Journal of Anxiety Disorders, 22(8), (2008), 1285-1296.

P.L. West, N.J. McKeown, R.G. Hendrickson, Massive hymenoptera envenomation in a 3-year-old. Pediatric Emergency Care, 27(1), (2011), 46-48.

H.U. Wittchen, N. Müller, H. Pfister, S. Winter, B. Schmidtkunz, Affektive,somatoforme und Angststörungen in Deutschland - Erste Ergebnisse des bundesweiten Zusatzsurveys „Psychische Störungen“. Gesundheitswesen SPEC NO, (1999), S216-222.

S.R. Woody, C. McLean, T. Klassen, Disgust as a motivator of avoidance of spiders. Journal of Anxiety Disorder, 19(4), (2005), 461-475. 


\section{Figures and Tables}

Figure 1: Differences between the different arthropods in the three scales "knowledge of the arthropod", "dangers associated with arthropods" and "anxiety and disgust".

Figure 2: Quotients of the medians of the estimated number of deaths associated with various activities or problems and the actual numbers obtained from the Statistisches Bundesamt (Federal Office for Statistics, http://www.destatis.de). They are depicted on a logarithmic scale. Red bars mean underestimation, blue bars overestimation.

Table 1: Characteristics of the probands.

\begin{tabular}{|l|c|}
\hline Variable & \\
\hline Gender [N (\%)] & $123(55.2)$ \\
Female & $99(44.4)$ \\
Male & $1(0.4)$ \\
Missing & \\
\hline Age [years] & 37.6 \\
Mean & 30.0 \\
Median & 18.0 \\
Standard deviation & $12-84$ \\
Range & \\
\hline Profession [N (\%)] & $93(41.7)$ \\
Undergoing education & $5(2.2)$ \\
Housewife & $5(2.2)$ \\
Unemployed & $6(2.7)$ \\
Unskilled worker & $47(21.1)$ \\
Skilled worker & $51(22.9)$ \\
Employee & $1(0.4)$ \\
Senior official & $15(6.7)$ \\
Pensioner &
\end{tabular}


Table 2: Subscales of the 'Fear of Arthropod Questionnaire': Cronbach's alpha of the entire scale $=0.93$

\begin{tabular}{|c|c|c|}
\hline Knowledge & Danger & Anxiety and Disgust \\
\hline Cronbach’s alpha $=0.58$ & $\begin{array}{l}\text { Cronbach's alpha = } \\
0.881\end{array}$ & Cronbach’s alpha $=0.93$ \\
\hline $\begin{array}{l}\text { I can clearly distinguish a } \\
\text { (name of arthropod) from } \\
\text { other similar animals. }\end{array}$ & $\begin{array}{l}\text { If I saw a (name of } \\
\text { arthropod) now I would } \\
\text { be afraid of it. }\end{array}$ & $\begin{array}{l}\text { If I saw a (name of } \\
\text { arthropod) now I would } \\
\text { probably break out in a } \\
\text { sweat }\end{array}$ \\
\hline $\begin{array}{l}\text { I have come across a } \\
\text { (name of arthropod) } \\
\text { before. }\end{array}$ & $\begin{array}{l}\text { I now would do anything } \\
\text { to try to avoid a (name of } \\
\text { arthropod). }\end{array}$ & $\begin{array}{l}\text { I am disgusted by a (name } \\
\text { of arthropod). }\end{array}$ \\
\hline $\begin{array}{l}\text { I know about the biology } \\
\text { of a (name of arthropod). }\end{array}$ & $\begin{array}{l}\text { I think that allergic } \\
\text { reactions to (name of } \\
\text { arthropod) are common }\end{array}$ & $\begin{array}{l}\text { Before I enter a room I } \\
\text { would control for the } \\
\text { absence of (name of } \\
\text { arthropod). }\end{array}$ \\
\hline \multirow[t]{5}{*}{$\begin{array}{l}\text { I am aware of the } \\
\text { ecological benefit of a } \\
\text { (name of arthropod). }\end{array}$} & $\begin{array}{l}\text { If I saw a (name of } \\
\text { arthropod) now, I would } \\
\text { think it would attack me. }\end{array}$ & $\begin{array}{l}\text { I would feel } \\
\text { uncomfortable if I saw the } \\
\text { picture of a (name of } \\
\text { arthropod) now. }\end{array}$ \\
\hline & $\begin{array}{l}\text { If I saw a (name of } \\
\text { arthropod) now, I would } \\
\text { feel very panicky. }\end{array}$ & $\begin{array}{l}\text { If I encountered a (name } \\
\text { of arthropod) now, it } \\
\text { would take a long time to } \\
\text { get it out of my mind. }\end{array}$ \\
\hline & $\begin{array}{l}\text { If I saw a (name of } \\
\text { arthropod) now, I would } \\
\text { think it would try to jump } \\
\text { on me. }\end{array}$ & $\begin{array}{l}\text { I would be somewhat } \\
\text { afraid to enter a room } \\
\text { now, where I have seen a } \\
\text { (name of arthropod) } \\
\text { before. }\end{array}$ \\
\hline & $\begin{array}{l}\text { I am afraid of the pain } \\
\text { associated with a (name } \\
\text { of arthropod) bite/sting }\end{array}$ & $\begin{array}{l}\text { If I came across a (name } \\
\text { of arthropod) now, I } \\
\text { would get help from } \\
\text { someone else to remove } \\
\text { it. }\end{array}$ \\
\hline & $\begin{array}{l}\text { I am afraid of the } \\
\text { numerous bites/stings of } \\
\text { a (name of arthropod). }\end{array}$ & $\begin{array}{l}\text { (Name of arthropod)s are } \\
\text { one of my worst fears. }\end{array}$ \\
\hline
\end{tabular}


Table 2 (continued): Subscales of the 'Fear of Arthropod Questionnaire': Cronbach's alpha of the entire scale $=0.93$

\begin{tabular}{|c|c|c|}
\hline & $\begin{array}{l}\text { I think that a bite/sting of } \\
\text { a (name of arthropod) is } \\
\text { likely when it sits on me. }\end{array}$ & $\begin{array}{l}\text { If I came across a (name } \\
\text { of arthropod) now, I } \\
\text { would leave the room. }\end{array}$ \\
\hline & $\begin{array}{l}\text { If I came across a (name } \\
\text { of arthropod) now, I } \\
\text { would run away. }\end{array}$ & $\begin{array}{l}\text { I hate (name of } \\
\text { arthropod)s. }\end{array}$ \\
\hline & $\begin{array}{l}\text { I would have great } \\
\text { difficulties in staying } \\
\text { calm if a (name of } \\
\text { arthropod) was around. }\end{array}$ & $\begin{array}{l}\text { I would do everything to } \\
\text { have (name of arthropod)s } \\
\text { removed when they are } \\
\text { living at a neighbour's } \\
\text { house. }\end{array}$ \\
\hline & $\begin{array}{l}\text { I would be very afraid of } \\
\text { a great number of nests of } \\
\text { (name of arthropod). }\end{array}$ & \\
\hline & $\begin{array}{l}\text { I get nervous when } \\
\text { someone says that a } \\
\text { (name of arthropod) is } \\
\text { around. }\end{array}$ & \\
\hline & $\begin{array}{l}\text { I am very afraid of an } \\
\text { allergic reaction to a } \\
\text { (name of arthropod) } \\
\text { bite/sting. }\end{array}$ & \\
\hline & $\begin{array}{l}\text { If I heard the sound of a } \\
\text { (name of arthropod), I } \\
\text { would feel very panicky. }\end{array}$ & \\
\hline
\end{tabular}


Table 3: Subscales of the Use and Problems of Arthropods Questionnaire

\begin{tabular}{|c|c|c|}
\hline Health \& Environment & Dangers / Allergies & Animal husbandry \\
\hline Cronbach's alpha $=0.78$ & Cronbach's alpha $=0.63$ & Cronbach's alpha $=0.52$ \\
\hline I like to eat honey & $\begin{array}{l}\text { Three hornet stings kill a } \\
\text { man, seven even a horse }\end{array}$ & I breed spiders \\
\hline Honey is a healthy food & $\begin{array}{l}\text { I know somebody with } \\
\text { an allergy to bee or wasp } \\
\text { stings }\end{array}$ & $\begin{array}{l}\text { I can imagine myself } \\
\text { keeping bees }\end{array}$ \\
\hline $\begin{array}{l}\text { I use bee products as a } \\
\text { health food }\end{array}$ & $\begin{array}{l}\text { I have been stung by a } \\
\text { bee }\end{array}$ & $\begin{array}{l}\text { I can imagine myself } \\
\text { keeping spiders }\end{array}$ \\
\hline $\begin{array}{l}\text { I look for quality and } \\
\text { origin of honey }\end{array}$ & $\begin{array}{l}\text { I have been stung by a } \\
\text { wasp }\end{array}$ & $\begin{array}{l}\text { I know somebody who } \\
\text { keeps spiders }\end{array}$ \\
\hline $\begin{array}{l}\text { Bees are an important part } \\
\text { of the ecosystem }\end{array}$ & & I know a beekeeper \\
\hline \multicolumn{3}{|l|}{$\begin{array}{l}\text { Bees contribute to the } \\
\text { production of food }\end{array}$} \\
\hline \multicolumn{3}{|l|}{$\begin{array}{l}\text { I am very interested in the } \\
\text { preservation of nature }\end{array}$} \\
\hline $\begin{array}{l}\text { am involved in } \\
\text { environment protection }\end{array}$ & & \\
\hline
\end{tabular}


Table 4: Bivariate correlations between the dimension "Knowledge of the arthropod” and other scales and demographic factors

\begin{tabular}{|c|c|c|c|c|c|c|c|}
\hline & & Knowle & & & & & \\
\hline & & Wasp & Spider & Bee & Ladybird & Woodlouse & Hornet \\
\hline & Wasp & 1 & & & & & \\
\hline & Spider & $.688 * *$ & 1 & & & & \\
\hline Knowledge & Bee & $.797 * *$ & $.713^{* *}$ & 1 & & & \\
\hline & Ladybird & $.565^{* *}$ & $.607^{* *}$ & $.619 * *$ & 1 & & \\
\hline & Woodlouse & $.553^{* *}$ & $.577^{* *}$ & $.466^{* *}$ & $.535^{* *}$ & 1 & \\
\hline & Hornet & $.553^{* *}$ & $.577 * *$ & $.466 * *$ & $.535 * *$ & $1.000^{* *}$ & 1 \\
\hline & Wasp & $-.321 * *$ & $-.167 *$ & $-.192 * *$ & $-.260 * *$ & $-.210^{* *}$ & $-.210^{* *}$ \\
\hline & Spider & $-.385^{* *}$ & $-.275^{* *}$ & $-.256 * *$ & $-.333^{* *}$ & $-.225^{* *}$ & $-.225^{* *}$ \\
\hline Danger & Bee & $-.404 * *$ & $-.253^{* *}$ & $-.307^{* *}$ & $-.284^{* *}$ & $-.223^{* *}$ & $-.223 * *$ \\
\hline & Ladybird & $-.293^{* *}$ & $-.286^{* *}$ & $-.268 * *$ & $-.285^{* *}$ & $-.151^{*}$ & $-.151^{*}$ \\
\hline & Woodlouse & $-.360 * *$ & $-.311^{* *}$ & $-.311^{* *}$ & $-.351^{* *}$ & $-.342^{* *}$ & $-.342 * *$ \\
\hline & Hornet & $-.305^{* *}$ & $-.134 *$ & $-.151^{*}$ & $-.231 * *$ & $-.236^{* *}$ & $-.236 * *$ \\
\hline & Wasp & $-.336 * *$ & $-.189 * *$ & $-.219 * *$ & $-.309^{* *}$ & $-.237 * *$ & $-.237 * *$ \\
\hline & Spider & $-.329 * *$ & $-.154 *$ & $-.209 * *$ & $-.240 * *$ & $-.147 *$ & $-.147^{*}$ \\
\hline Anxiety & Bee & $-.379 * *$ & $-.222 * *$ & $-.313^{* *}$ & $-.312^{* *}$ & $-.226^{* *}$ & $-.226^{* *}$ \\
\hline Disgust & Ladybird & $-.279 * *$ & $-.223^{* *}$ & $-.236 * *$ & $-.269 * *$ & $-.146^{*}$ & $-.146^{*}$ \\
\hline & Woodlouse & $-.341 * *$ & $-.232 * *$ & $-.264^{* *}$ & $-.295^{* *}$ & $-.349 * *$ & $-.349 * *$ \\
\hline & Hornet & $-.317^{* *}$ & $-.132 *$ & $-.180^{* *}$ & $-.268 * *$ & $-.243^{* *}$ & $-.243^{* *}$ \\
\hline Age [Years] & & $.227 * *$ & n.s. & $.201 * *$ & $.267 * *$ & $.136^{*}$ & $.136 *$ \\
\hline Gender & & n.s. & n.s. & n.s. & n.s. & n.s. & n.s. \\
\hline State Anxiety & & $-.153 *$ & $-.137 *$ & n.s. & n.s. & $-.169 *$ & $-.169 *$ \\
\hline Trait Anxiety & & $-.176^{* *}$ & n.s. & n.s. & $-.150 *$ & $-.187^{* *}$ & $-.187^{* *}$ \\
\hline Neuroticism & & $-.174 *$ & $-.142 *$ & $-.153^{*}$ & $-.175^{*}$ & $-.151^{*}$ & $-.151^{*}$ \\
\hline Extraversion & & n.s. & $.246^{* *}$ & $.174 *$ & $.211^{* *}$ & $.170^{*}$ & $.170^{*}$ \\
\hline Openness & & $.299 * *$ & $.287^{* *}$ & $.286^{* *}$ & $.294 * *$ & $.317 * *$ & $.317 * *$ \\
\hline Agreeableness & & $.235^{* *}$ & $.229 * *$ & $.221 * *$ & $.272 * *$ & $.253 * *$ & $.253 * *$ \\
\hline Diligence & & $.211^{* *}$ & n.s. & $.218 * *$ & $.189 * *$ & $.167 *$ & $.167 *$ \\
\hline Positive Affects & & $.170^{*}$ & $.255^{* *}$ & $.188^{* *}$ & $.330 * *$ & $.191^{* *}$ & $.191 * *$ \\
\hline Negative Affects & & n.s. & n.s. & $-.136 *$ & $-.174 *$ & n.s. & n.s. \\
\hline Health \& Enviro & ment & $.355^{* *}$ & $.219 * *$ & $.294 * *$ & $.310^{* *}$ & $.332 * *$ & $.332 * *$ \\
\hline Dangers / Allerg & & $-.339 * *$ & $-.294^{* *}$ & $-.286^{* *}$ & $-.275^{* *}$ & $-.272^{* *}$ & $-.272 * *$ \\
\hline Animal husbandr & & $.304^{* *}$ & $.166 *$ & $.188 * *$ & $.183^{* *}$ & $.294 * *$ & $.294 * *$ \\
\hline
\end{tabular}


Table 5: Bivariate correlations between the dimension "Perceived danger of the arthropod" and other scales and demographic factors

\begin{tabular}{|c|c|c|c|c|c|c|c|}
\hline & & \multicolumn{6}{|l|}{ Danger } \\
\hline & & Wasp & Spider & Bee & Ladybird & Woodlouse & Hornet \\
\hline \multirow{6}{*}{ Danger } & Wasp & 1 & & & & & \\
\hline & Spider & $.653 * *$ & 1 & & & & \\
\hline & Bee & $.813^{* *}$ & $.643^{* *}$ & 1 & & & \\
\hline & Ladybird & $.253^{* *}$ & $.503 * *$ & $.372 * *$ & 1 & & \\
\hline & Woodlouse & $.480 * *$ & $.732 * *$ & $.474 * *$ & $.641^{* *}$ & 1 & \\
\hline & Hornet & $.875^{* *}$ & $.632 * *$ & $.724^{* *}$ & $.186^{* *}$ & $.449 * *$ & 1 \\
\hline \multirow{6}{*}{$\begin{array}{l}\text { Anxiety } \\
\text { Disgust }\end{array}$} & Wasp & $.798 * *$ & $.737 * *$ & $.655^{* *}$ & $.387 * *$ & $.642 * *$ & $.683 * *$ \\
\hline & Spider & $.604 * *$ & $.880 * *$ & $.555^{* *}$ & $.357 * *$ & $.615^{* *}$ & $.576 * *$ \\
\hline & Bee & $.683^{* *}$ & $.708^{* *}$ & $.785^{* *}$ & $.505^{* *}$ & $.605^{* *}$ & $.571^{* *}$ \\
\hline & Ladybird & $.358 * *$ & $.551^{* *}$ & $.425 * *$ & $.776^{* *}$ & $.624 * *$ & $.290 * *$ \\
\hline & Woodlouse & $.529 * *$ & $.692^{* *}$ & $.461 * *$ & $.472 * *$ & $.876^{* *}$ & $.506^{* *}$ \\
\hline & Hornet & $.744 * *$ & $.726^{* *}$ & $.612^{* *}$ & $.320 * *$ & $.607 * *$ & $.818 * *$ \\
\hline \multicolumn{2}{|l|}{ Age [Years] } & $-.135^{*}$ & n.s. & n.s. & n.s. & n.s. & $-.226 * *$ \\
\hline \multicolumn{2}{|l|}{ Gender } & $.145^{*}$ & $.216^{* *}$ & $.202^{* *}$ & n.s. & n.s. & $.152 *$ \\
\hline \multicolumn{2}{|l|}{ State Anxiety } & $.197 * *$ & $.298 * *$ & $.192 * *$ & $.413^{* *}$ & $.334 * *$ & $.189 * *$ \\
\hline \multicolumn{2}{|l|}{ Trait Anxiety } & $.259 * *$ & $.372 * *$ & $.217 * *$ & $.316^{* *}$ & $.300^{* *}$ & $.249 * *$ \\
\hline \multicolumn{2}{|l|}{ Neuroticism } & $.248 * *$ & $.379 * *$ & $.235^{* *}$ & $.256^{* *}$ & $.324 * *$ & $.286^{* *}$ \\
\hline \multicolumn{2}{|l|}{ Extraversion } & n.s. & $-.146 *$ & n.s. & $-.197 * *$ & $-.199 * *$ & n.s. \\
\hline \multicolumn{2}{|l|}{ Openness } & $-.263^{* *}$ & $-.293^{* *}$ & $-.277^{* *}$ & $-.319 * *$ & $-.361^{* *}$ & $-.228 * *$ \\
\hline \multicolumn{2}{|l|}{ Agreeableness } & $-.235 * *$ & $-.298^{* *}$ & $-.240 * *$ & $-.298^{* *}$ & $-.345^{* *}$ & $-.237 * *$ \\
\hline \multicolumn{2}{|l|}{ Diligence } & n.s. & $-.138 *$ & n.s. & $-.212^{* *}$ & $-.268 * *$ & n.s. \\
\hline \multicolumn{2}{|l|}{ Positive Affects } & $-.183^{* *}$ & $-.294 * *$ & $-.195^{* *}$ & $-.282^{* *}$ & $-.312 * *$ & $-.165^{*}$ \\
\hline \multicolumn{2}{|l|}{ Negative Affects } & $.191 * *$ & $.223^{* *}$ & $.156^{*}$ & $.231^{* *}$ & $.224 * *$ & $.173^{*}$ \\
\hline \multicolumn{2}{|c|}{ Health \& Environment } & n.s. & n.s. & n.s. & n.s. & n.s. & n.s. \\
\hline \multicolumn{2}{|c|}{ Dangers / Allergies } & $.191 * *$ & $.175^{* *}$ & $.164 *$ & $.194 * *$ & $.229 * *$ & $.221 * *$ \\
\hline \multicolumn{2}{|l|}{ Animal husbandry } & $-.278^{* *}$ & $-.204 * *$ & $-.281^{* *}$ & n.s. & n.s. & $-.278 * *$ \\
\hline
\end{tabular}


Table 6: Bivariate correlations between the dimension "Anxiety and disgust” and other scales and demographic factors

\begin{tabular}{|c|c|c|c|c|c|c|c|}
\hline & & $\begin{array}{l}\text { Anxiety } \\
\text { Wasp }\end{array}$ & Spider & Bee & Ladybird & $\begin{array}{l}\text { Woodlous } \\
\mathrm{e}\end{array}$ & Hornet \\
\hline $\begin{array}{l}\text { Anxiety } \\
\text { Disgust }\end{array}$ & $\begin{array}{l}\text { Wasp } \\
\text { Spider } \\
\text { Bee } \\
\text { Ladybird } \\
\text { Woodlouse } \\
\text { Hornet }\end{array}$ & $\begin{array}{l}1 \\
.770^{* *} \\
.843^{* *} \\
.538^{* *} \\
.721 * * \\
.868^{* *}\end{array}$ & $\begin{array}{l}1 \\
.704^{* *} \\
.490^{* *} \\
.683^{* *} \\
.760^{* *}\end{array}$ & $\begin{array}{l}1 \\
.644^{* *} \\
.635^{* *} \\
.740^{* *}\end{array}$ & \begin{tabular}{|l}
1 \\
$.633^{* *}$ \\
$.454^{* *}$
\end{tabular} & $\begin{array}{l}1 \\
.696^{* *}\end{array}$ & 1 \\
\hline \multicolumn{2}{|l|}{ Age [Years] } & n.s. & $-.185^{* *}$ & $-.152 *$ & n.s. & n.s. & $-.220 * *$ \\
\hline \multicolumn{2}{|l|}{ Gender } & $.166^{*}$ & $.304 * *$ & $.201^{* *}$ & n.s. & n.s. & $.187^{* *}$ \\
\hline \multicolumn{2}{|l|}{ State Anxiety } & $.239 * *$ & $.241^{* *}$ & $.236^{* *}$ & $.307^{* *}$ & $.313^{* *}$ & $.247 * *$ \\
\hline \multicolumn{2}{|l|}{ Trait Anxiety } & $.222^{* *}$ & $.269 * *$ & $.215^{* *}$ & $.275 * *$ & $.290 * *$ & $.245 * *$ \\
\hline \multicolumn{2}{|l|}{ Neuroticism } & $.250^{* *}$ & $.271^{* *}$ & $.244^{* *}$ & $.233^{* *}$ & $.322 * *$ & $.290 * *$ \\
\hline \multicolumn{2}{|l|}{ Extraversion } & n.s. & n.s. & n.s. & n.s. & $-.192 * *$ & n.s. \\
\hline \multicolumn{2}{|l|}{ Openness } & $-.322^{* *}$ & $-.219 * *$ & $-.335^{* *}$ & $-.286^{* *}$ & $-.320^{* *}$ & $-.297 * *$ \\
\hline \multicolumn{2}{|l|}{ Agreeableness } & $-.351^{* *}$ & $-.257 * *$ & $-.340^{* *}$ & $-.320^{* *}$ & $-.357^{* *}$ & $-.339 * *$ \\
\hline \multicolumn{2}{|l|}{ Diligence } & $-.162^{*}$ & n.s. & $-.135 *$ & $-.233^{* *}$ & $-.270 * *$ & n.s. \\
\hline \multicolumn{2}{|l|}{ Positive Affects } & $-.188^{* *}$ & n.s. & $-.162^{*}$ & $-.233^{* *}$ & $-.223^{* *}$ & $-.154^{*}$ \\
\hline \multicolumn{2}{|l|}{ Negative Affects } & $.161^{*}$ & $.139 *$ & $.174 *$ & $.222 * *$ & $.210 * *$ & $.153^{*}$ \\
\hline \multicolumn{2}{|c|}{ Health \& Environment } & $-.138^{*}$ & n.s. & $-.140^{*}$ & n.s. & n.s. & $-.168^{*}$ \\
\hline \multicolumn{2}{|c|}{ Dangers / Allergies } & $.187 * *$ & n.s. & $.138 *$ & $.178^{* *}$ & $.208 * *$ & $.202 * *$ \\
\hline \multicolumn{2}{|c|}{ Animal husbandry } & $-.218^{* *}$ & $-.225^{* *}$ & $-.207^{* *}$ & n.s. & $-.214^{* *}$ & $-.238 * *$ \\
\hline
\end{tabular}



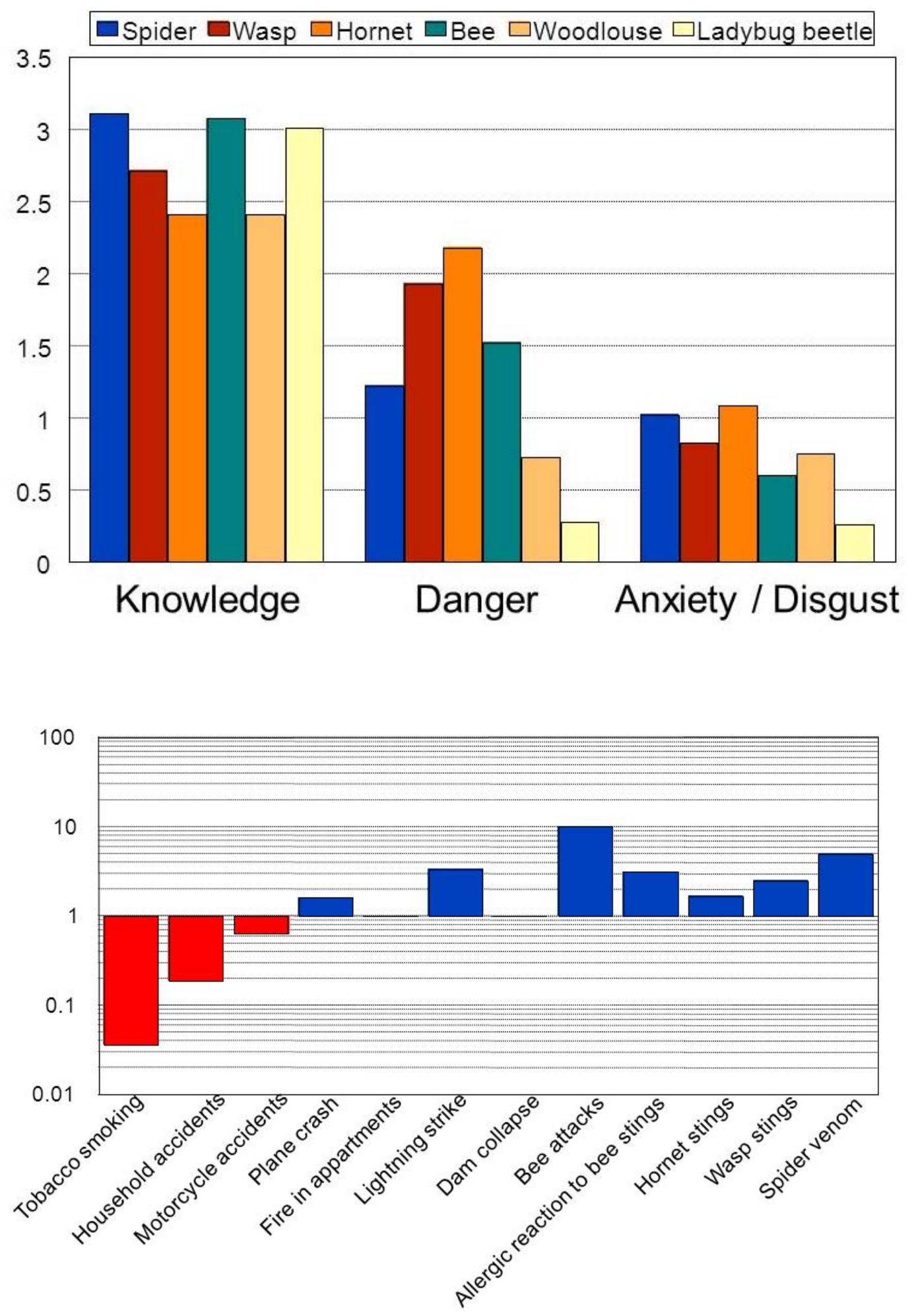
Received: January 8, 2013 